\title{
Antibody-Dependent Enhancement (ADE) of infection and its possible role in the pathogenesis of influenza
}

\author{
Isabelle Dutry ${ }^{1,2^{*}}$, Hui-ling Yen ${ }^{1,2}$, Horace Lee ${ }^{1}$, Malik Peiris ${ }^{1,2}$, Martial Jaume ${ }^{1}$ \\ From Institut Pasteur International Network Annual Scientific Meeting \\ Hong Kong. 22-23 November 2010
}

Antibody-dependent enhancement (ADE) of viral replication has been documented for viruses, such as dengue virus, Ross river virus, other alpha and flaviviruses, HIV and also influenza virus. ADE occurs when non-neutralised virus-antibody complexes find alternative receptors and routes entry into the cell via the Fc-receptor pathway. ADE has been demonstrated predominantly in macrophages or Fc-receptor bearing cells although other types of cells have also been occasionally implicated $(1,2)$. Thus, viruses may find routes of entry to cells lacking the usual virus receptor. Alternatively, the innate immune signals triggered by virus infection via the FcR pathway may be different to those triggered by entry via the physiological virus receptor. Both these consequences may have implications for virus tropism and pathogenesis. Recently there have been reports of increased infection rates by pandemic influenza H1N1 virus following receipt of seasonal flu vaccination $(3,4)$. ADE has been proposed as one mechanism. Here we illustrate the possible role played by humoral immunity in providing Influenza A viruses an opportunity to better infect immune cells.

Our results showed that, in some cases, prior addition of human serum to the inoculum triggered an enhanced infection of target cells as illustrated by a $\sim 2-5$ fold increase in Influenza M-gene copy numbers. Immunofluorescent microscopy revealed that serum-mediated pdmH1N1 infection led to a higher number of infected cells. As the fold increase of infected cells paralleled the fold change in viral gene copies, we conclude that ADE was acting by increasing the number of infected cells rather than solely increasing the viral load per cell.

'HKU-Pasteur Research Centre, Hong Kong, Hong Kong SAR

Full list of author information is available at the end of the article
Based on their ability to enhance pdmH1N1 infectivity, human sera could be divided into 3 distinct groups: some showing neutralization of infection, others increasing the yield of pdmH1N1-infected cells. The third group were those with no or marginal increase of virus infection, one which was not sustained over the tested range of serum dilutions.

Our results demonstrate that the newly emerged pandemic H1N1 Influenza A virus infection of cells of the hematopoietic lineage may be enhanced by the presence of some human sera. In the light of the recent studies that report possible associations between vaccination and increased susceptibility to influenza infection, it is of relevance to deepen our understanding of the biological significance and molecular mechanisms underlying serum-mediated ADE infection of influenza virus.

\section{Author details}

${ }^{1}$ HKU -Pasteur Research Centre, Hong Kong, Hong Kong SAR. ${ }^{2}$ Department of Microbiology, The University of Hong Kong, Hong Kong SAR.

Published: 10 January 2011

\section{References}

1. Gotoff R, Tamura M, Janus J, Thompson J, Wright P, Ennis FA: Primary influenza $A$ virus infection induces cross-reactive antibodies that enhance uptake of virus into Fc receptor-bearing cells. J Infect Dis 1994, 169:200-203.

2. Takada A, Kawaoka Y: Antibody-dependent enhancement of viral infection: molecular mechanisms and in vivo implications. Rev Med Virol 2003, 13:387-398.

3. Skowronski DM, De Serres G, Crowcroft NS, et al: Association between the 2008-09 seasonal influenza vaccine and pandemic H1N1 illness during Spring-Summer 2009: four observational studies from Canada. PLoS Med 2010, 7:e1000258.

4. Kobinger GP, Meunier I, Patel A, et al: Assessment of the efficacy of commercially available and candidate vaccines against a pandemic H1N1 2009 virus. J Infect Dis 2010, 201:1000-1006.

( 2011 Dury aricensee Boms

๑ 2011 Dutry et al; licensee BioMed Central Ltd. This is an open access article distributed under the terms of the Creative Commons Attribution License (http://creativecommons.org/licenses/by/2.0), which permits unrestricted use, distribution, and reproduction in any medium, provided the original work is properly cited. 
doi:10.1186/1753-6561-5-S1-P62

Cite this article as: Dutry et al: Antibody-Dependent Enhancement

(ADE) of infection and its possible role in the pathogenesis of influenza.

BMC Proceedings 2011 5(Suppl 1):P62.

Submit your next manuscript to BioMed Central and take full advantage of:

- Convenient online submission

- Thorough peer review

- No space constraints or color figure charges

- Immediate publication on acceptance

- Inclusion in PubMed, CAS, Scopus and Google Scholar

- Research which is freely available for redistribution

Submit your manuscript at 